\title{
Packaging Design Elements and Users Perception: A Context in Fashion Branding and Communication
}

\author{
Heer Vyas \\ National Institute of Fashion Technology \\ heervyas4@gmail.com \\ Bhuvanesh V. \\ National Institute of Fashion Technology
}

\begin{abstract}
The product packaging has a crucial role to attract consumer, force them to choose the product and act as a brand communication vehicle. The point of focus is how the elements of the package design affect consumer's perceptions about products and brand. In this study, we collected data through a questionnaire that covered areas such as design elements of the package (size, shape, material, graphic design of package, typography, images and pictures), user's perception (attention, purchase and repurchase) and their experience (feelings evoked and functional benefits). There is a difference with the professional status and age involvement with respect to response on packaging. The findings also suggest that consumers associate different benefits to various elements of package design.
\end{abstract}

Key Words: shape, typography, material, graphics 


\section{INTRODUCTION}

Packaging has become a primary vehicle for communication and branding [1]. Packaging is an important factor in purchase decision made at point of sale and also plays a role of a salesman on the shelf. Certain features in packaging are required to be included according to the legislative and regulatory requirements. In addition, the packaging has many functions such as protect the goods from the environment, attract the consumers and provide information to the customers $[2,3]$.These functions of packaging are served by the varied design elements.

There are studies which have identified the functions of individual packaging design elements such as color, image, shape, material, label and typography and the perception of the consumer. The form or exterior appearance of a product is means to communicate information to consumers [4]. Product form creates the initial impression and generates inferences regarding other product attributes. Size impacts the visibility of package and information displayed [5].Silayoi and Speece (2004) reported that package size, shape and elongation affects customer judgments and decisions. Graphics includes layout, color combinations, typography, and product photography, these aids to create an image, impact the brand communication and marketing and consumer mind set [6]. Color is a tool for brand identification and visual distinction [7] .Singh (2006) states that color has an important influence on advertising, certain qualities such as eleganeness and others. It is also an important factor for legibility of the texts and comprehension of the images placed on the package. The material has an influence on quality image on consumers' minds [10]. Photographs and illustrations on packaging are powerful design tools to identify the product difference, communicate product functions, and impart emotional imagery [7]. Studies shows that it is feasible to manipulate the imagery and position of product by selecting and using different design elements [7]. This will influence the perception of the product and thereby directly influence the consumer's buying decision.

There are studies that have attempted to explore the packaging on food and food processed products. There is limited literature on packaging and its influence on consumer with respect to fashion products. We will try to find out how important package design attributes are for their like, choose, purchase, attention, recall and brand communication. 


\section{METHODOLOGY}

\section{Questionnaire}

A questionnaire was administered amongst 102 individuals. We asked the participants demographic details about age, gender and occupation. Hundred and two respondents answered the questionnaire. $46 \%$ of the respondents were female. $55 \%$ of the respondents were professional ( $45 \%$ were students). Almost all the respondents were young. The participants answered the questions pertaining to packaging elements and its influence on their mindset.

We asked them their frame of mind after seeing a product package which included like the product, get attracted to the product, purchase the product, choose the product, repurchase the product and their understanding of the brand. We asked them details about elements of package such as color, typography, shape, material, graphic layout, visual information, bright colors, redeem label and pictures. Further, we also asked them questions about their experience about the functional benefits of the packaging. In particular (1) Attractiveness, position and sign of the logo, (2) verbal information, (3) usage of colors and its softness and brightness, (4) readability of font and its ease to remember (5) Attention drawing ability of shape and size (6) Uniqueness of the Material and (7) Usefulness of the information on the package (Appendix 1) .

\section{Statistics Analysis}

IBM Statistical Software for Social Science 21 SPSS 21 was employed. Descriptive statistics was used to calculate frequencies of each item. ANOVA was employed to understand whether there was change in response to packaging attributes with respect to demographic variables (age, gender and occupation). Correlation statistics was used to examine relation ship between consumers response (getting attracted, choosing and purchasing product, packaging as promotion vehicle and brand communicator) and packaging design attributes.

\section{RESULTS AND DISCUSSION}

Consumers subconsciously assign subjective values to package based on their color, shape and the basic materials [7]. Packages perform a major role in enhancing brand equity by fortifying brand awareness, purchase decision and building brand images via conveying functional, symbolic, and experiential benefits (Shimp, 2001; Sara, 1990). There are previous studies more focused on verbal elements, due to a lack of understanding of visual design attributes. This study aimed to investigate the linkage between design attributes of packages and user perception and response.

\section{Packaging \\ \& Its Influence on Consumer Mind}

Hundred and two respondents answered the questionnaire. $46 \%$ of the respondents were female. $55 \%$ of the respondents were professional ( $45 \%$ were students). Almost all the respondents were young. After seeing the package, $90 \%$ of the respondents like the product, $92 \%$ get attracted, $89 \%$ of the respondents purchase and $73 \%$ repurchase the product. Packaging helps consumers to choose (84\%), get an impression about the product and repurchase $(73 \%)$ the product.

Packaging influenced the consumer response towards the product (89\%), lead to impulsive buying $(69 \%)$ and differentiate the brand (84\%) (Figure 1). Packaging strategies exert an influence on time taken for purchase $(83 \%)$, brand promotion $(87 \%)$ and communicate about the brand (84\%). After having a visual contact with the packaging, respondents felt that products suits their need $(46 \%)$, suits their taste $(46 \%)$, invoke love for domestic product $(45 \%)$, improves their mood (46\%), evoke satisfaction (45\%) and draw them to pay extra (49\%). 


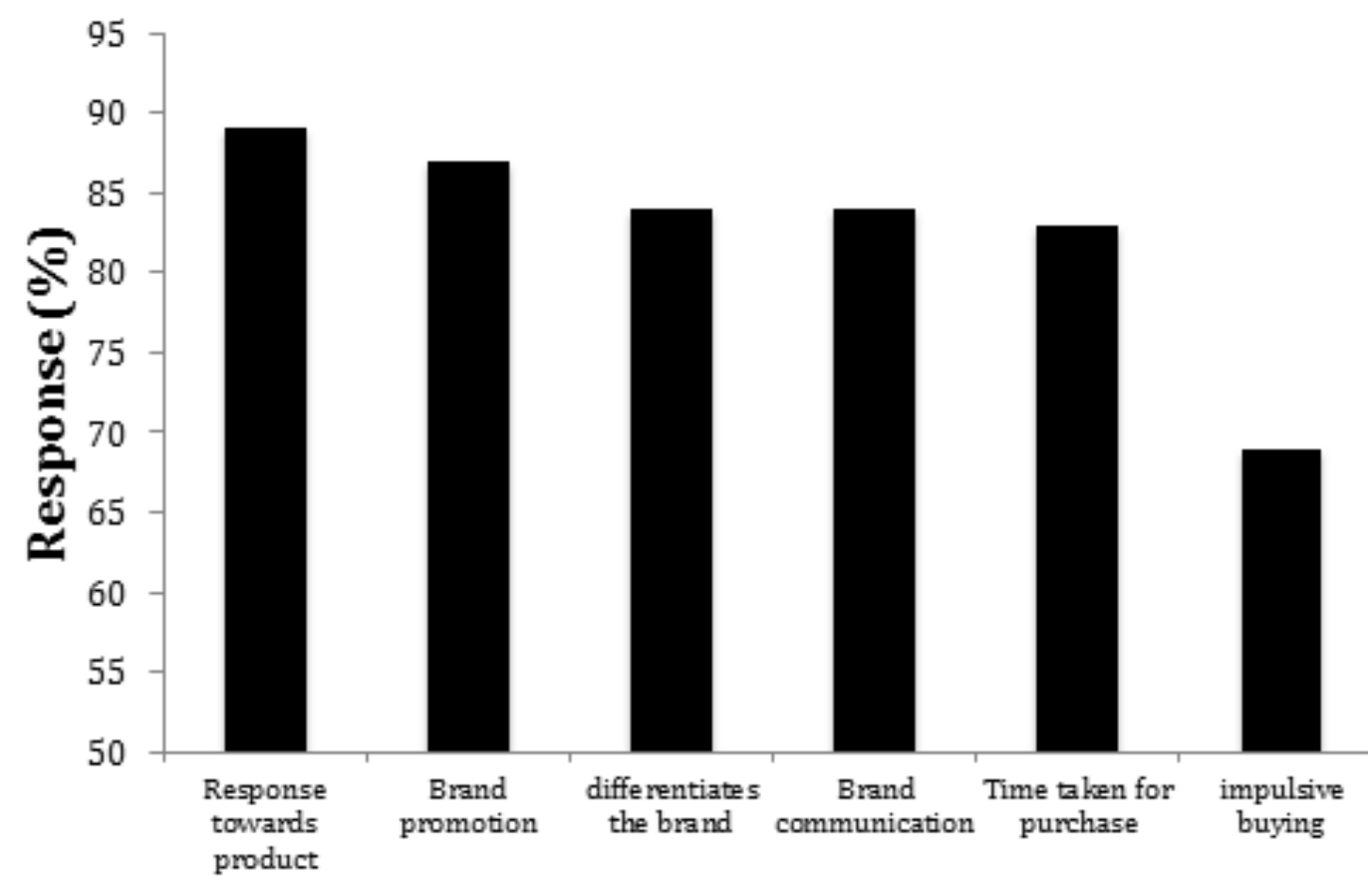

\section{Consumer Response}

Figure 1. Consumers response to packaging

\section{Users Response to Elements of Package Design}

The basic elements of package design are name, shape, color, typography, material, product information and image. We examined the association of these packaging attributes with response of consumer's mind in relation to packaging. Name of the brand on package draws attention (43\%), easy to remember (43\%) and make it unique (47\%). Color combination of packaging draws attention (46\%), easy to remember (47\%), evokes the mood (49\%) and differentiates the products $(48 \%)$. Font on package draws attention (47\%) and is readable from a distance $(43 \%)$ by consumers. Picture on packaging draws attention (46\%), triggers' purchase (46\%) and makes it easy to remember the product $(50 \%)$.
The shape of the package was attributed to drawing attention (47\%), ease of finding it in stores (47\%) and comfort to carry(48\%). Packaging size suits the need for the amount required (48\%), ease to carry $(50 \%)$ and encourages them to buy it (47\%). Product information on the package is clear (45\%), draws trust (49\%) and is easy to follow (46\%). The color of the brand evoked mood (84\%) and sensory feelings amongst the consumers. $72 \%$ of the consumers felt that typography on the package influenced the readability of the instructions on package. Graphics on the package sought attention (91\%) and the boring feeling $(75 \%)$. 


\begin{tabular}{|c|c|c|}
\hline \multicolumn{3}{|l|}{ Elements of packaging } \\
\hline Packaging element & Influence on consumer & Response (\%) \\
\hline \multirow[t]{3}{*}{ Name of the brand } & Draw attention & 43 \\
\hline & Ease to remember & 43 \\
\hline & Make it unique & 47 \\
\hline \multirow[t]{4}{*}{ Color combination } & Draw attention & 46 \\
\hline & Ease to remember & 47 \\
\hline & Evoke mood & 48 \\
\hline & Differentiate the products & 49 \\
\hline \multirow[t]{2}{*}{ Font } & Draw attention & 47 \\
\hline & Readable from distance & 43 \\
\hline \multirow[t]{3}{*}{ Picture on packaging } & Draw attention & 46 \\
\hline & Trigger purchase & 46 \\
\hline & Ease to remember & 5 \\
\hline \multirow[t]{3}{*}{ Picture on packaging } & Draw attention & 46 \\
\hline & Trigger purchase & 46 \\
\hline & $\begin{array}{l}\text { Ease to remember the } \\
\text { product }\end{array}$ & 50 \\
\hline \multirow[t]{3}{*}{ The shape of package } & Draws attention & 47 \\
\hline & $\begin{array}{l}\text { Ease of finding in the } \\
\text { store }\end{array}$ & 47 \\
\hline & Comfort to carry & 48 \\
\hline \multirow[t]{3}{*}{ Packaging size } & $\begin{array}{l}\text { Suit the need for amount } \\
\text { required }\end{array}$ & 48 \\
\hline & Ease to carry & 50 \\
\hline & Encourage to buy product & 47 \\
\hline \multirow{3}{*}{$\begin{array}{l}\text { Product information and } \\
\text { description }\end{array}$} & Clarity & 45 \\
\hline & Draws trust & 49 \\
\hline & Ease to follow & 46 \\
\hline Color of the brand name & $\begin{array}{l}\text { Evoke mood and sensory } \\
\text { feelings amongst the } \\
\text { consumers. }\end{array}$ & 84 \\
\hline Graphics on the package & Sought attention & 91 \\
\hline Visual information & Attracts to the product & 85 \\
\hline Logo & Position is crucial & 83 \\
\hline \multirow[t]{2}{*}{ Package material } & $\begin{array}{l}\text { Gives a feel of sign of } \\
\text { quality }\end{array}$ & 83 \\
\hline & Evoke feelings & 82 \\
\hline
\end{tabular}

Table 1. Consumers response to packaging elements 


\section{Change in Response to Packaging With Demographic Variables}

The study aimed to whether the difference in gender, age group, professional involvement and educational status influence the response in packaging.Studies have reported that consumers of different ages have different needs and wants (Michael R. Solomon 1996 p. 13). With an increase in age there was a higher probability of them selecting the products with pictures on packaging (ANOVA F 3.2;p<0.05).
Professionals gave a higher response to like the product based on packaging, choose product because of packaging, considering packaging as promotion vehicle, color on package drawing attention, image on package being significant, shape of packaging, graphics on package drawing attention and shape of package meeting storage need compared to students. There were no differences reported with change in gender and educational status on packaging design elements and consumers response.

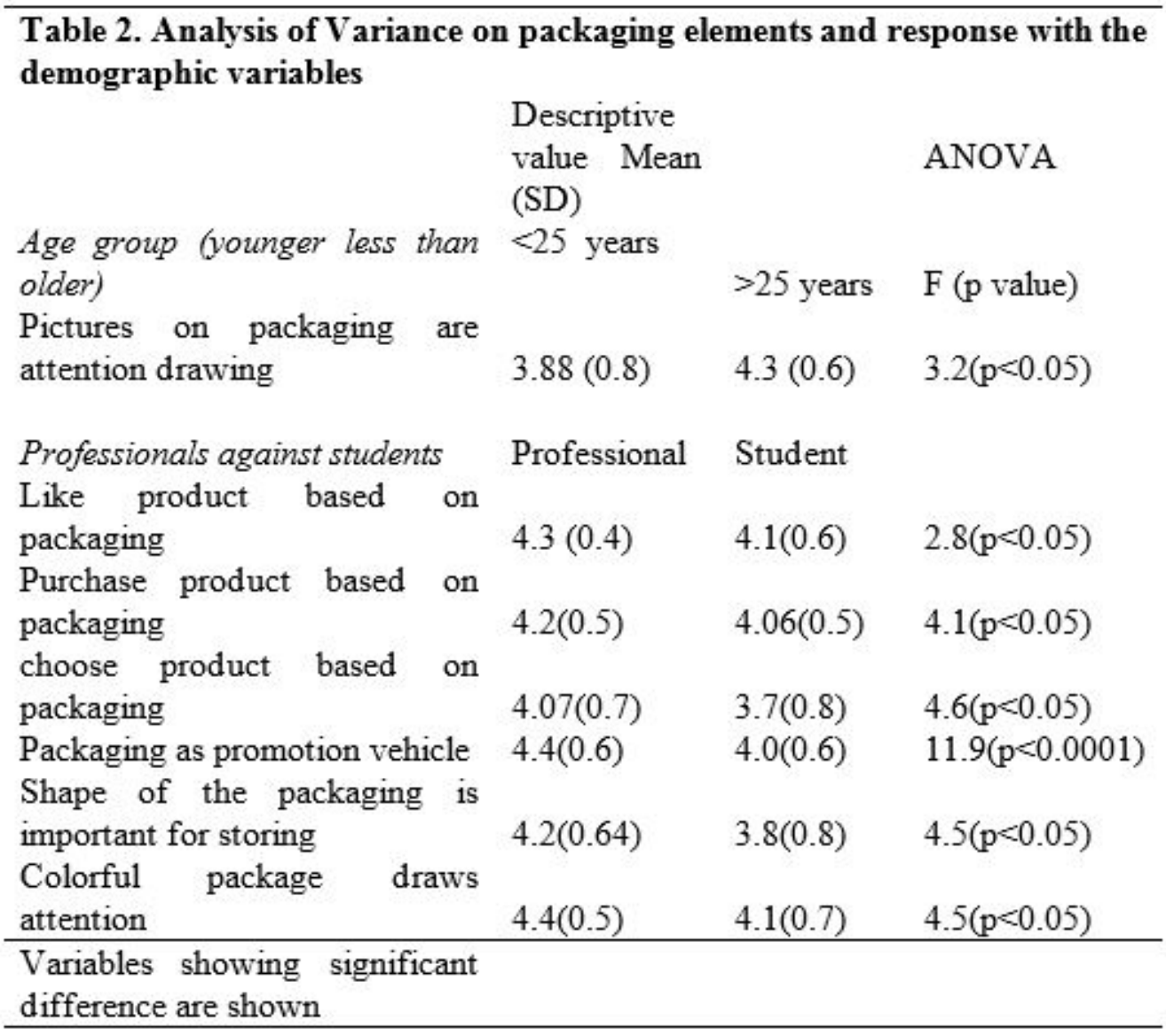

Table 2: Analysis of varriance on packaging elements response with the demographic variables 


\section{Association Between Packaging Design Attributes and Consumer Response}

We calculated correlation statistics between packaging design elements and consumers response.

Shape of the packaging was associated with consumer response such as like and attracted to the product and deliver brand value. Size and shape of the package have been related to functional benefits such as the amount needed and ease to carry, experiential benefits such as symbolism and image drawing and finding it in the store [11]. This nature of functional benefits associated with the form of the package delivers the positive response towards packaging.

Pictures were associated with like, purchase, attracted and impressed by the product, communicate the brand value and act as a brand communication vehicle. Pictures on packaging draws attention, communicate brand meaning, affect sensory product information, make them more attractive, and evoke an emotional response [12]. The emotional response of consumers to pictures was elicited in form of getting attracted and impressed by the product and considering the package as brand communication vehicle.

Logo position was associated with liking of the product, getting attracted and impressed to the product, purchasing the product, choosing the product, brand communication and as a promotion vehicle. Logo shapes are known to convey a certain essence and also helps to make a familiar identity about the brand [11]. When consumers get the essence of the logo, they respond positively to the package and thereby the brand.

Colors on packaging were significantly associated with consumers getting to like, choose, being attracted and being impressed by the product. Colors were also associated with the perception that packaging serves as a brand communication vehicle and provides the brand value. Moriarty (1991) discusses color, mentioning that color in advertising serve a variety of specific purposes. Color creates moods, draws attention, emphasizes, generates emotional responses and intensifies memorability [9] . These emotional responses were exhibited by the consumers in form of getting attracted, choose and purchase the products. Morarity further states that color can be used as a cue, to either associate with or symbolize something else. Colors on packaging would have lead them to associate with the brand and symbolize certain value that on packaging the color served to act as a brand communication vehicle and deliver brand value.

Typography was associated with purchase, choose and impress the product and as a brand communication vehicle and delivering the brand value. The verbal communication elements are of critical importance because they are responsible for communicating specific information about the product and its attributes [12]. The graphics techniques used to display the words create a distinct impression, resulting in that the appearance in the type also carries meaning. The styling of the words by the graphics designer can tell the consumer much about the product. Every information element on the package has to be precisely targeted and presented in an easy-to-read manner to communicate the intended brand and product information $[12,14]$.For designers who attempt to create positive psychological or emotional connections should concentrate on different packaging elements. 
Table 3. Correlation values between packaging design elements and consumers perception

Influence on the consumer after seeing the package (only statistically significant associations have been shown)

\begin{tabular}{|c|c|c|c|c|c|c|c|}
\hline $\begin{array}{l}\text { Variables of packaging } \\
\text { design elements }\end{array}$ & $\begin{array}{l}\text { Like the } \\
\text { Product }\end{array}$ & $\begin{array}{l}\text { Get } \\
\text { attracted } \\
\text { to product }\end{array}$ & $\begin{array}{l}\text { Purchase } \\
\text { the } \\
\text { product }\end{array}$ & $\begin{array}{l}\text { Choose } \\
\text { the } \\
\text { product }\end{array}$ & $\begin{array}{l}\text { Impress } \\
\text { with the } \\
\text { product }\end{array}$ & $\begin{array}{l}\text { Packaging } \\
\text { as a brand } \\
\text { Promotion } \\
\text { Vehicle }\end{array}$ & $\begin{array}{l}\text { Packaging } \\
\text { delivers } \\
\text { brand } \\
\text { value }\end{array}$ \\
\hline $\begin{array}{l}\text { Packaging shape(curve \& } \\
\text { straight) on packaging is } \\
\text { interesting }\end{array}$ & $0.3^{*}$ & $0.48^{* * *}$ & & & & & $0.228^{*}$ \\
\hline $\begin{array}{l}\text { Shape attracts by showing } \\
\text { comfortless to hold } \\
\text { Image sub dimension }\end{array}$ & & $0.2^{*}$ & & & & & \\
\hline $\begin{array}{l}\text { attracts towards the } \\
\text { product }\end{array}$ & $0.237^{*}$ & & $0.2^{*}$ & & $0.204^{*}$ & $0.226^{*}$ & $0.221^{*}$ \\
\hline $\begin{array}{l}\text { Good quality material in the } \\
\text { packaging }\end{array}$ & & $0.289(* *)$ & $0.486(* *)$ & $0.476(* *)$ & $0.311(* *)$ & $0.278(* *)$ & \\
\hline $\begin{array}{l}\text { High quality packaging } \\
\text { Visual information attracts }\end{array}$ & & $0.414(* *)$ & $0.354(* *)$ & $0.344(* *)$ & $0.386(* *)$ & & \\
\hline towards a specific product & & & $0.261^{*}$ & $0.454^{* * *}$ & $0.304^{*}$ & & 0.419 \\
\hline $\begin{array}{l}\text { Design of the logo is } \\
\text { attractive }\end{array}$ & $0.206^{*}$ & $0.314^{* *}$ & $0.4^{* * *}$ & 0.195 & & 0.181 & $0.27^{*}$ \\
\hline $\begin{array}{l}\text { Position of the logo is } \\
\text { attractive on package } \\
\text { Sign of the logo is attractive }\end{array}$ & $0.32^{*}$ & $0.331^{*}$ & $0.218^{*}$ & $0.258^{*}$ & $0.212^{*}$ & & \\
\hline on package & $0.287^{* *}$ & & & $0.318^{*}$ & $0.22^{*}$ & $0.31^{*}$ & \\
\hline Aggressiveness & & & & & & & \\
\hline typography & & & $0.28^{*}$ & $0.225^{*}$ & $0.224^{*}$ & $0.249^{*}$ & $0.227^{*}$ \\
\hline $\begin{array}{l}\text { Graphic layout on } \\
\text { packaging is interesting }\end{array}$ & $0.316^{*}$ & $0.42^{* * *}$ & $0.28^{*}$ & $0.27^{*}$ & $0.25^{*}$ & 0.208 & $0.29^{*}$ \\
\hline $\begin{array}{l}\text { Pictures on packaging are } \\
\text { interesting }\end{array}$ & $0.4^{* * *}$ & $0.266^{* *}$ & & & $0.24^{*}$ & $0.244^{*}$ & $0.264^{* *}$ \\
\hline $\begin{array}{l}\text { Softness and brightness of } \\
\text { the color attracts attention } \\
\text { Colorful package catches }\end{array}$ & $0.24^{*}$ & & $0.204^{*}$ & 0.11 & $0.21^{* *}$ & $0.362^{* *}$ & $0.24^{*}$ \\
\hline attention & $0.34^{* *}$ & $0.314^{* *}$ & $0.435^{* * *}$ & $0.325^{* *}$ & $0.295^{* *}$ & $0.24^{*}$ & $0.34^{* *}$ \\
\hline
\end{tabular}

Table 2: Correlation values between packaging design elements and consumer's perception 


\section{CONCLUSION}

Different packaging elements had functional implications on users mind. ANOVA studies showed that there is difference in demographic variables based on age groups and professional involvement. Correlation studies suggested that the packaging design elements have an influence on choosing, getting attracted, like, purchase the product and considering packaging as a brand promotion vehicle. Most of the respondents showed positive response to shape, typography, pictures, material, quality and color. Visual components are more effective and influential for packaging design, as they are noticed by consumers directly and communicate quickly at the point of purchase. The study finds an important implication of individual packaging design elements and also understands the importance of each element on consumer mindset. The packaging designers must precisely target and present the visual and verbal content to communicate the intended brand and product information 


\section{REFERENCES}

[1] Rettie, R, and Brewer, C. "The verbal and visual components of package design," Journal of Product \& Brand Management, (2000), vol 9 (1), pp 56- 68.

[2] Sonneveld, K. "What drives (food) packaging innovation?," Packaging Technology and Science, 2000, vol 13, pp 29-35.

[3] Olsson, A and Györei, M. "Packaging throughout the value chain in the customer perspective marketing mix," Packaging Technology and Science.2002 15, 231- 239.

[4] Bloch, P. "Seeking the ideal form: product design and consumer response," Journal of marketing, (1995) vol .59, pp.16-29.

[5] Sonsion, Packaging design: graphics, materials, technolog 1990 , Van Nostrand Reinhold,Technology \& Engineering

[6] Silayoi, P. and Speece, M. "Packaging and purchase decisions: a focus group study on the impact of involvement level and time pressure," British Food Journal, 2004, Vol. 106( 8), pp. 607-28.

[7] Meyers-Levy, J. and Peracchio, L. "Understanding the effects of colour: how the correspondence between available and required resources affects attitudes," 1995, Journal of consumer research, vol 22(2);pp121-139.

[8] Underwood, R. L. (2003). "The communicative power of product packaging: creating brand identity via lived and mediated experience,"Journal of Marketing Theory \& Practice, vol 11(1),pp 62-76.
[9] Singh, Satyendra. "Impact of color on marketing." Management decision 44.6 (2006): 783-789.

[10] Sauvage, F. (1996),"The marketing aspect of packaging", In Food packaging technology (Vol. 1, pp. 33-47). United States: VHC Publishers.

[11] Schmitt, B. \& Simonson, A. (1997), "Marketing Aesthetics,". New York: The Free Press.

[12] Underwood, R. L., Klein, N. M., Burke, R. R. (2001). "Packaging communication: attentional effects of product imagery," Journal of Product \& Brand Management, vol 10 (7), pp 403-422.

[13] Meyers, H, and Lubliner, M. J., "The Marketer's Guide to Successful Package Design. IIIinois: NTC Business Books.

[14] Cahyorini, Astri, and Effy Zalfiana Rusfian. "The effect of packaging design on impulsive buying," Bisnis \& Birokrasi Journal 2012, 18.1. 


\section{APENDIX 1 QUESTIONAIRE}

Name

Age

Gender

Occupation you work

\section{Frame of mind after seeing the product packaging}

You like the product

Get attracted to the product

Attracted to purchase

Helps to choose a product

Repurchase the product

Impressed to the product

Packaging design becomes a brand's promotional vehicle to highlighting its position.

Brand name decides my purchase.

Color draws my attention and creates good mood.

Typography catches my attention and makes easy to read.

Shape of package attracts by showing comfort to hold.

Image sub-dimension attracts me towards the product

Packaging design are capable of creating the strong urge toward instant purchase.

\section{What is the impact of packaging on your mindset}

Perfect package influence my purchasing decisions

I decide quality based on package.

Some package contains high quality and apt design.

Packaging design's function is to visually communicate the product difference.

\section{Please comment on packaging sub dimensions}

A Product's material may affect consumer perception of its quality

Packaging material can evoke emotions and certain feelings

Shape affects the protection and comfort function in storing

Does the packaging methods creates competitive spirits and friendly atmosphere?

Packaging placement and display also affect impulsive packaging.

Purchase of new products results from impulsive buying rather than planned buying.

Colorful package catches my attention 1st

If package is dull and boring, I don't purchase

Visual information makes me to attract towards a specific product 
Graphic design affects impulsive designing.

The details on the package influence my purchasing decisions.

Packaging methods saves the consumer's purchasing time.

\section{Please answer these questions related to packaging for fashion products}

Brand name 'packaging draws my attention

Brand name is unique compared to other brand

Brand name on packaging is easy to remember

Packaging color composition on packaging draws attention

Packaging color composition on packaging is easy to remem

Packaging color composition stands out on the shelves compared to other brand

Packaging color composition on packaging creates a good mood

Font on packaging draws my attention

Font is readable from 1 meter distance

Picture on the packaging is easy to remember

Picture on packaging draws my attention

Picture on packaging makes me go for purchase

Packaging shape on packaging draws my attention

Packaging shape on packaging makes it easy to store

Packaging shape on packaging is comfortable to hold

Packaging size suits my needs

Packaging size on packaging encourages me to buy it

Packaging size on packaging is easy to carry

Packaging material draws attention

Packaging material on packaging is unique compared to other brands

Product information on packaging is described clearly

Product information on packaging inspires trust for the product

Storage information on packaging is easy to follow

Desire to buy after visual contact

No obstacles in buying

After visual contact, feeling that is what I need

After visual contact, feeling that is suits my taste

Animation dimension evokes love for domestic products

Purchasing can improve mood

Purchasing evoke satisfaction

I would like to pay extra for packaging with the product or service 
Identify the factors which make a good packaging for the fashion products

Attractiveness of the logo

Position of the logo

Sign of the logo

Quality of verbal information

Aggressiveness of typography

Usage of varied colors

Softness and Brightness of the colors

Harmonious color schemes

Packaging plays an important role in purchasing.

Degree of structure and detailing methods of product motivating purchase.

To trigger impulsive buying, marketers create unique and attractive packaging decisions.

Packaging design are capable of creating the strong urge toward instant purchase.

Did u get product information based on packaging?

Packaging factors gets your attention and increase urge towards purchasing.

Graphic layout grabs your attention

Pictures on packaging

Visual information on packaging

Bright colors

Packaging shape(curve \& straight) 